\title{
COMPARISON BETWEEN MYTHICAL NARRATIVES OF CORPORATE CULTURE AND NATIONALISTIC CULTURE
}

Boris Petrović

Paris Sorbonne,

Paris, France

\begin{abstract}
:
This research examines how the nationalistic model of culture and corporate culture are essentially similar notions and should be analyzed as such. Our main hypothesis is that the ideology of nationalism was created to serve as a cultural foundation of a nation-state, which was in its turn created to act as a legal frame and a protector of interest of the industrial capitalistic mode of production. The necessity of such a research is self-evident-the current historical context is that of a world shaken by a recent surge of nationalism (Brexit, election of Donald Trump as the president of the U.S.A, Catalonian crisis in Spain), seen by many as a response to the ongoing process of globalization. Globalized corporations evading the legal (and cultural) frames of nation-states; certain companies (Google, Apple, Facebook) show tendencies of accumulating more capital and power than many, or even most nation states. This inquiry proposes an outline of more detailed research into the relationship between a nation state and corporation, especially into the cultural and ideological formulation of one and the other.
\end{abstract}

Keywords:

capitalism, nationalism, corporation, globalization, myth-making.

Nationalistic ideology is a recent phenomenon, dating from the late $18^{\text {th }}$ century and developed and fully elaborated in the $19^{\text {th }}$ century. Leading scholars in the field (Benedict Anderson, Ernst Geller, and Anthony D. Smith, to name a few) agree that it is, as a phenomenon, inextricably linked to the industrial revolution and the capitalistic mode of production. In other words, nationalism is an ideological formulation of the industrial capitalistic mode of production upon which the nation-state (the currently globally recognized form of statehood) is built. It is important to underline this connection from the very beginning - nationalism and industrial capitalism—as we shall compare the cultural model of a nation state to that of a corporation.

It is also important to underline the proximity of the industrial development of the European countries to their colonial endeavors. One could not be possible without the other. As Ernst Gellner stated:

"There is also a link between nationalism and the processes of colonialism, imperialism and de-colonization. The emergence of industrial society in Western Europe had as its consequence the virtual conquest of the entire world by European powers, and sometimes by European settler population. In effect the whole of Africa, America, Oceania, and very large parts of Asia came under European domination; and the parts of Asia which escaped this fate were often under strong indirect influence."

Colonialism is essential for the proper understanding of the cultural matrix of nationalism, especially the essential trait of a nationalistic narrative-that of superiority of one's culture (which in turn justifies and legitimizes colonial expansion - "the white man's burden"). International corporations nowadays follow the $19^{\text {th }}$ century colonial narrative to the letter- they install production where labor is cheap and regulation is "flexible" (or nonexistent). This understanding is important not only on account of
1 Gellner, E. (1983). Nations and Nationalism. Ithaca, New York: Cornell University Press, p.42. 
proper historical framing of the development of a nationalistic and corporate mythical narrative, but first and foremost for proper understanding of its current situation.

Nationalism relies on the idea of a unity of people who come together to form a society. Anthony D. Smith singles out four decisive factors, four most important cohesive agents-community, territory, history, and destiny. ${ }^{2}$ Whereas community (in itself comprising shared culture, language etc.), territory and history are quite self-explanatory, the fourth aspect is interesting and requires further inquiry. Destiny, apart from seemingly veering into the realm of poetic expression, is the aspect looking toward the future, whereas the former ones are linked to the past and/or present. Destiny is a common goal, something to strive for, a shared unifying vision around which society gathers. Whereas community, territory and (especially) history can be to a certain point accidental, destiny is the most active and galvanizing of all of the aspects. This statement, of course, is to be properly situated within the nationalistic discourse (that relies on mythologizing and instrumentalizing history to further its agenda) - it is not the position of the presentation's author. It is a way of practicing the values that define the society and every individual that constitutes the said society, in service of a common goal.

In a nationalistic paradigm, a society is comprised of individuals-sum of all the individual members of the community creates a nation. The bonds that bind them, four key aspects that we mentioned, create a common cohesive agent that forms a cultural, political and finally state entity.

This is where the structural comparison between a nation and a corporation begins. A corporation (from Latin corpus, the body, but also a sum, a collection of different parts acting together) is an assembly of people authorized to act as a single entity. By its legal and substantial definition, a corporation bears the idea of a group (notion of many) acting as a singular entity. Meaning, a group of different individuals is fused into one by a pursuit of the same interest (even though such a group in most cases is represented by a prominent individual). A corporation is therefore a supra-entity, one made out of many different entities (individuals) and often, through a process of merger, even other supra-entities (corporations). The goal of such a supra-entity is to be able to last longer than the sum of its parts. When one worker retires, another one takes his or her place. That way, a supra-entity can survive, in theory at least, indefinitely. ${ }^{3}$

As we can see, the very definition of a corporation is remarkably similar to that of the nation. Indeed, a nation is

2 Smith, A. D. (2003). Chosen Peoples. New York: Oxford University Press Inc., p. 31

3 We can take the Swedish mine of Kopparberg as an example - as a corporation, it has been in existence since the $13^{\text {th }}$ century, with royal approval given by the Swedish king in 1347; long before nationalism was formulated as an ideology.

4 More often than not, violently and against the will of the peoples in this manner "fused". also a group assembled through the pursuit of the same interest. A nation is also a supra-entity - one that is made out of different entities (individuals), also sometimes a product of 'fusion' of other, smaller nations, or tribes, or ethnicities. A notion of a Briton, for example, 'fuses' already existing notions of a Welshman, an Englishman, a Scotsman etc. ${ }^{4}$ Much like with the corporation, the goal of a nation is to perpetuate (and often expand) its proper culture and existence well beyond what a singular individual is capable of. As a supraentity, nationalistic corpus can last, in theory, forever; when a member dies, another will take his or her place. That way, a nation can outlast a sum of all of its parts.

The notion of entity is closely related to that of identity-a specific nationalistic culture that defines a given nation and renders it unique among other nations-specificities of language, history, and core values of its ethos. ${ }^{5}$ The national identity of the group (the community of a nation) defines members of the group from above downwards-the (idealized image of) nation that is the supra-entity projects its model downwards onto the individuals who constitute the corpus of a nation. As Anthony D. Smith states:

"If it is true that those units stand the best chance of forming nations which are constructed around an ancient ethnic core, then both 'history' and 'landscape' become essential vehicles and molds for nation-building. But their greatest influence is indirect; through the myths and symbols of community which they evoke. Herein lies their 'communitycreating' potency, and here too we find the roots of their directive capacity. ${ }^{6}$ For, once unearthed and appropriated, the mythology and symbolism of poetic spaces and golden ages casts its own social spell."

The accepted attitude of $19^{\text {th }}$ and $20^{\text {th }}$ century nationalistic ideology is that nations are formed around the idea of uniqueness, especially in a competitive (in that respect very similar to corporate) environment, surrounded by other, often enemy nations:

"The nation was defined as closely integrated, united in its struggle for survival and fundamentally different from the neighbouring countries on the continent. It was recognized primarily through distinct traits and ethnic profile. ${ }^{\prime \prime}$

In this manner, the nations act competitively one against another; much like corporations do in the open, free market. Such competition is necessary, because the main defining force is that it is the "enemy" of the nation, much like the staple argument for an existence of the free market is that

5 Most nations pride themselves in similar characteristics, such are courage, love of freedom, hospitality, chivalry, deep connection to their homeland, love of native scenery etc., yet they all feel and act as those traits are singular and unique to their nation. Could the same be said about corporate cultures?

6 Our italic.

7 Smith, A. D. (1995). The Ethnic Origins of Nations. Cambridge, USA: Blackwell Publishers Inc., p. 200.

8 Bouchard, G. (2005). Genèse des nations et cultures du Nouveau Monde. Gatineau, Quebec: Boreal Compact. P. 111.

9 According to the main structural features of the mythical narrative. 
competition forces the corporation to strive for excellencewhat Marx defines as the coercive quality of the capitalistic mode of production. We can easily translate this to the nationalistic model of culture - existence and ambition of other nations, especially their territorial pretentions and cultural aspirations galvanize "our" nation and force it to excel.

However, the modern nation can be created around a cultural model rather than an ethnic "core"-a path to follow in the creation of an international corporation, where ethnicity, history, territory and language cannot be shared, but the culture can - with it, foundational values and principles:

"Two centuries ago, the nation was conceived as a particular form of political unity: "its specificity is reflected in integrating people into the citizens' community, whose existence legally regulates external and internal activities of the State" (Dominique Schnapper, La Communauté des citoyens, Gallimard, 1994, p. 28). Therefore, the modern nation is different from ethnic groups that are not necessarily politically organized: ethnicity usually evokes historical and cultural heritage of a community. ${ }^{10}$

Much like nations, corporations should also (and do) seek to constantly reinvent themselves and keep their culture alive. It is a living organism, a "body" that, much like a regular body, needs to constantly recreate and renew itself in order to survive (again, competing against other bodies for resources and dominance):

"Creating nations is a recurrent activity, which has to be renewed periodically. It is one that involves ceaseless reinterpretations, rediscoveries and reconstructions; each generation must re-fashion national institutions and stratification systems in the light of the myths, memories, values and symbols of the 'past', which can best minister to the needs and aspirations of its dominant social groups and institutions. Hence that activity of rediscovery and re-interpretation is never complete and never simple; it is the product of dialogues between the major social groups and institutions with the boundaries of the 'nation', and it answers to their perceived ideals and interests. ${ }^{11}$ "

Corporations that act in the open market are by definition in constant competition. Competition is the very foundation of the free-market, capitalistic economy. Not surprisingly, the same can be said of nations. They are in constant competition, be it based on defensive or offensive grounds. One nation always proclaims its superiority over others, and strives to achieve it. As is stated:

"Nationalism, it is claimed, assumes that the people of one's nation are superior to the people of all other nations. This means that nationalism is always poised for domination of other nations, or that nations are permanently poised to

10 Sironneau, Jean-Pierre (1995) IRIS, Centre de recherche sur l'imaginaire - Université de Grenoble III, Numéro 15, directrice de publication Danièle Chauvin, p. 10.

11 Smith, A. D. (1995). The Ethnic Origins of Nations. Cambridge, USA defend themselves from domination. Fear is a permanent feature of all nations. ${ }^{12 "}$

Especially as of late, when we consider major global companies (Facebook, Google, Apple) taking the notion of the corporate culture seriously, the same can be said of a corporation. The corporation projects its cultural model downwards onto all of its members. A nationalistic hero in this term is to be regarded the same as the corporate one. $\mathrm{He}$ is the mythical being who can do the impossible, driven by a higher goal - one that acts as an inspiration for all of the workers, and most importantly, he acts as a socially cohesive agent. In this manner, a special research can be made on the topic of mythisation of the cult of personality of a corporate and a nationalistic hero - for example, General Custer and Steve Jobs. In both cases, the mythical narrative follows the same structure and uses the same topoi; an unlikely hero rose above the circumstances, achieved great things, fought bravely for his vision and died in a blaze of glory, in his prime, at the very apex of his endeavor.

An important distinction is to be made here-we are talking about the employees of a company, not their clients. The internal corporate culture of a company such as Google or Apple is not the same (although, of course, there are overlaps) as the image they project onto their consumers. This is a specific topic to be explored in greater and due detail in a separate research.

The crux of the main hypothesis of this presentation and the element that is to be researched with greatest attention is the similitude between the model of a national culture (that relies on patriotism) and that of a corporate culture. A corporation can be seen at the same time as a micro-nation, speaking in terms of numbers (rare are the corporations that would have over several hundred thousands of individuals involved, whereas nations easily go up to tens and hundreds of millions) and a macro-nation, speaking in terms of the territorial spread and the cultural reach (Google covers almost the entire planet; Coca-Cola too; Elon Musk's Space-X is developing a plan of Mars colonization, attempting to become not only an international but an interplanetary entity).

We shall therefore outline points of similitude between these two models that are to be examined. Both the nationalistic and corporate narratives are built around these notions:

- Loyalty to the supra-entity

- The notion of one's identity being largely derived from the supra-identity

- The notion of this identity being projected downwards, crystalized in mythical heroic figures that serve as examples

- Feeling a strong sense of belonging to the given culture

- A sense of community

12 Stander, S. (2014). Why War, Capitalism and the Nation-State. New York: Bloomsbury Academic, p. 69. 
- Shared values within a given ideology

- Micro (and macro) patriotism that spans different levels.

- The key aspect of social cohesion and of motivation: a heroic narrative built around a heroic figure. In case of corporations, the likes of Henry Ford, Elon Musk, Steve Jobs, Bill Gates etc.; in case of nations, 'founding fathers' the cult of personalities are spun around of - the likes of George Washington, Thomas Jefferson, Stalin, Mao Zedong, Charles de Gaulle etc.

To substantiate this, we can invoke a study that deals with corporate culture (though without making the connection to a nationalistic mythical narrative). Let us take a quick overview of the Content section of the book Corporate Culturesit gives a great insight into as a well as a solid substantiation of our main hypothesis, that a nation building mythical narrative based in the ideology of nationalism is essentially the same as the corporation building mythical narrative used in creation and perpetuation of a corporate culture and its core aspect, its mythical narrative. Much like in a nationalistic model, we have a strong presence of rituals and rites, heroic figures that inspire "the stuff of legend" that in turn incite social cohesion; most importantly, the study insists on the core aspect of the nationalistic ideology, that of shared "core values", the very foundational element of any ideology.

"Part I cultures:

Chapter 1: Strong Cultures: The New “Old Rule” for business success

Chapter 2: Values: The Core of the Culture

Chapter 3: Heroes: The Corporate Right Stuff

Chapter 4: Rites and Rituals: Culture in Action

Chapter 5: Communications: Working the Cultural Network

\section{Part II: Putting Cultures into Practice}

Chapter 6: Corporate Tribes: Identifying the Cultures

Chapter 7: Diagnosis: Learning to Read Cultures

Chapter 8: Symbolic Managers: Managing the Culture

Chapter 9: Change: Reshaping Cultures

Chapter 10: Cultures of the Future: The Atomized Organization"13

A comparison is to be made between this model of heroic individual (a corporate pioneer) and a national(istic) hero. We can clearly see that it is the same mythical narrative. As Anna Makolkin states speaking of a nationalistic mythical narrative:

"Having proclaimed poets as 'universal figures', and having elevated them to the level of divinity, the nineteenth-century thinkers worked out the philosophical ground of later

13 Deal, T. \& Kennedy, A. (1988). Corporate Cultures, The Rites and Rituals of Corporate Life. London: Penguin Business, Contents. nationalism and redefined the heroic role of men of letters as new social actants, new heroic subjects. The power of the word and verbal art had been rediscovered by the new European nations in the $19^{\text {th }}$ century when the national groups recognized literature as one of the best forms of expressing collective creativity. The desire of each nation was to create a unique collective ' $\mathrm{I}$ ', through common traditions, heritage, shared symbolism and mythology." 14

This examination is especially relevant today (presentation given December $1^{\text {st }} 2017$ ) in the post-Brexit context when global and local tendencies in both economy and politics are openly clashing; when corporations seem to take on the prerogatives of nation states; most importantly, when international companies find themselves in a cultural and legal vacuum. Legal and cultural systems are still built around the notion of the nation-state, and many companies that act internationally use this as a yet unsorted advantage when it comes to declaring taxes, hiring cheaper labor, bypassing regulation etc. Also, whereas nationalistic politics and ideology were the main source of the construction of an individual identity in a nation state, corporations project their own identity both onto their consumers and their employees. An individual identity as well as a broader question of identity politics (the sense of belonging to a group) can today be read through brands a person consumes (Apple, Starbucks, Facebook, Twitter, just to name a few, as well as a host of fashion and "lifestyle" brands individuals use to define themselves with) and identifies with equally or more so than a sense of belonging to a given nation. One of the main hypotheses to be substantiated is that they are instrumentalizing the same mythical narrative as the one that is used in building a nation state, albeit in a fragmented manner.

This is the key research aspect due to the potential practical usage of such an investigation. The research can be useful in these principal directions:

1. An examination of how corporations build a corporate culture using a historically and culturally (still) much more developed model of nation building. How this mythical narrative is being used to develop, enhance and then perpetuate the sense of loyalty, purpose and belonging.

2. An examination of corporate identity politics, focusing on the fact that a corporation treats its culture like a narrative, a discourse - a logical, both syncretic and eclectic assembly of all elements and aspects of culture. Having a company logo, or a company color scheme; or an entire visual identity (as they all do) does not cover the complex exigency at hand; having an established set of core values; having a business plan of development. All of these elements (and many more), are-it is our hypothesis-bound together in

14 Makolkin, A. (1992). Name, Hero, Icon, Semiotics of Nationalism through Heroic Biography. Mouton de Groyter: Berlin - New York, p. 21 . 
a coherent, dynamic narrative. They reflect an image, a body (corpus), a supra-identity that is projected downwards onto the people who constitute the supraentity, that of corporation and that of nation.

3. The main and final usage of this exploration comes from the dual perspective-that of the corporate owner and that of the corporate employee; the one whose interest is to project the given image (to inspire loyalty, even sacrifice when needed-as nationalistic narratives often do) but also the one upon whom that image is being projected. The purpose of the examination is to make the employee of a company aware of the process $\mathrm{s} /$ he is being submitted to; able to deconstruct that narrative, to see its flaws and shortcomings, as well as possible abuses and instrumentalizations.

4. Furthering the point of the third statement, these are the questions to be addressed: What type of employee is susceptible to this type of narrative? Is it a psychological profile of a person who lacks individual, national or familial identity and therefore seeks to fill it in with consumer and corporate one? Is conscientious usage of this narrative ethical-if so, to which extent? If we are to adopt a hypothesis that this model is a replica of the nationalistic mythical narrative, should we fear the exacerbation of the narrative into a form of "corporate fascism" (much like how the European nationalisms of the first half of the $20^{\text {th }}$ century mutated into fascism)?

5. Developing the notion of the instrumentalization of a nationalistic mythical narrative in the corporate context, the same question is to be posed as the one from the fourth statement, only in a different direction. Namely, can this narrative be used "for good"? Can the progress of technology be driven by a narratively framed set of values? Can communal spirit and more equitable division of profit be stimulated by the said sense of belonging? Could this sense of shared purpose be used to develop a functional "self-governing" corporate model? Can it enhance the quality of professional engagement of an employee through the development of a sense of purpose?

\section{CONCLUSION}

The purpose of the proposed research is to open ways into understanding not only historical, but structural similitudes between these two models of culture, corporate and nationalistic, and their corresponding mythical narratives. Having the historic experience of the first half of the $20^{\text {th }}$ century behind us, could we use this similitude in mythical narratives to predict and avoid the "mutation" of a corporate mythical narrative into something akin to nationalistic fascist ideology? One use that promises to be of immediate practical value is a better definition of a corporate culture and better understanding of the interior dynamics of a corporation, especially the one that is being created-both from the perspective of the worker and that of the owner - comprising the complexities of the corporate ownership (boards, investors, holdings etc.).

\section{LITERATURE}

Bouchard, G. (2005). Genèse des nations et cultures du Nouveau Monde. Gatineau, Quebec: Boreal Compact.

Deal, T. \& Kennedy, A. (1988). Corporate Cultures, The Rites and Rituals of Corporate Life. London: Penguin Business, Contents.

Gellner, E. (1983). Nations and Nationalism. Ithaca, New York: Cornell University Press.

Makolkin, A. (1992). Name, Hero, Icon, Semiotics of Nationalism through Heroic Biography. Mouton de Groyter: Berlin - New York.

Sironneau, Jean-Pierre. (1995). IRIS, Centre de recherche sur l'imaginaire - Université de Grenoble III, Numéro 15, directrice de publication Danièle Chauvin.

Smith, A. D. (2003). Chosen Peoples. New York: Oxford University Press Inc.

Smith, A. D. (1995). The Ethnic Origins of Nations. Cambridge, USA: Blackwell Publishers Inc.

Stander, S. (2014).Why War, Capitalism and the Nation-State. New York: Bloomsbury Academic. 